\title{
BORATES IN THE ARGENTINE PUNA: A NEW APPLICATION OF MAGNETIC SEPARATION
}

\author{
H.R. FLORES AND P. VILLAGRAN \\ Instituto de Beneficio de Minerales, CONICET, Universidad Nacional de \\ Salta, Buenos Aires 177 - 4400 Salta, Argentina
}

(Received June 19, 1991; in final form October 21, 1991)

\begin{abstract}
Large, highly marketable deposits of borate are situated in the north-western Argentina. The exploitation of these deposits started in the beginning of this century. The exploitation and industrialization of some of these deposits during the 1980s turned the region into an important trading centre for export of raw borates and of boric acid.

Technical specifications, as regards the iron content in those products, are very rigorous, particularly if they are used in manufacture of high-quality glass. This paper presents a survey of the borate industry in the Puna region of Argentina. A purification technique for "hard borates", based on magnetic separation is described. THe study has been carried out using pilot- plant magnetic separators at the IN BE MI, The Salta National University.
\end{abstract}

\section{DEPOSITS AND THEIR CHARACTERISTICS}

The main borate deposits in the world are in the U.S. A. (California), Turkey, Russia and South America. China, Italy and Germany have smaller deposits that are sufficient to meet only the local demand.

The U.S.A. is the main supplier of borates in the Western Hemisphere, while Turkey is the leading exporter in Europe. South America has a surplus of borates; Brazil and Argentina being the main consumers. Attempts to export borates to Japan and Europe have been made, with encouraging prospects. 


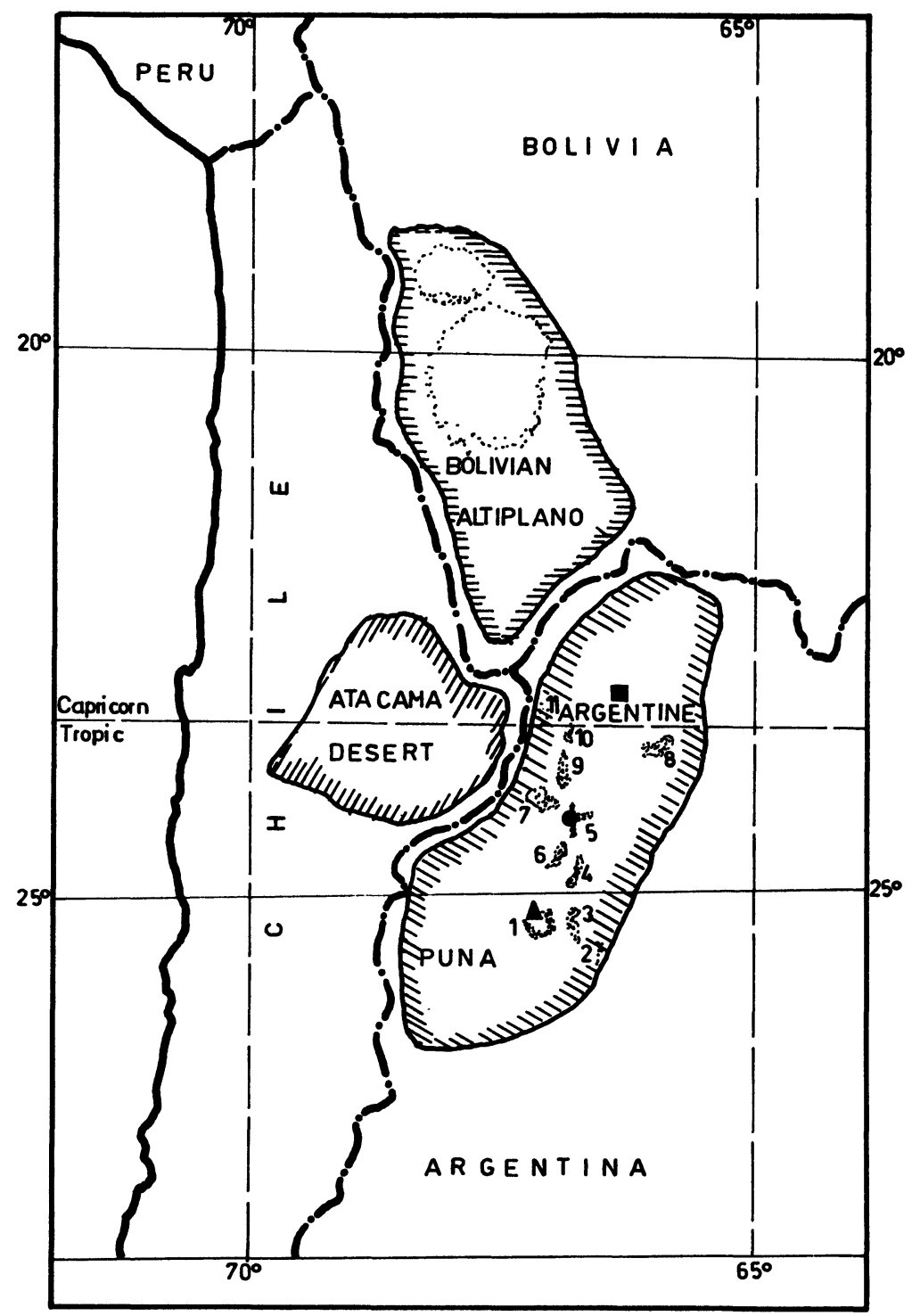

Salt lokes:
1. Hombre Muerto
4. Centenario
8. Salinas Crandes Borate deposits:
2. Diablillos
5. Pastos Grandes
Cauchari
- Sijes
3. Ratones
6. Pozuelos
10.0laroz
$\triangle$ Tincalayu
- Loma Blanco

7. Rincön

FIGURE 1 Geographical location of the Argentine Puna. Main salt lakes and borate deposits 
Accumulation of sodium, calcium and magnesium hydroborates is usually found among different types of borate deposits. It originates from evaporation of superficial water in a desert basin. The region of Central Andes is a huge evaporation zone which is divided into various basins, including the Bolivian Altiplano, the Argentine Puna and the Atacama Desert in Chile. The geography of the region is shown in Figure 1.

The Argentine Puna encompasses a strip about $200 \mathrm{~km}$ wide and $500 \mathrm{~km}$ long. Borate deposits can be found as:

- $\quad$ interlayered borate beds in the upper Miocene rocks

- $\quad$ borate deposits in the playa lake or salar environments

- $\quad$ geyser and thermal spring borates (presently almost exhausted).

Borax, colemanite, hydroboracite, inoyoite and ulexite are the main mineralogical species available in considerable quantities $[1,2]$. The Sijes mine alone contains the principal reserves of hydroboracite in the world, and the major reserves of colemanite in South America [3]. Economic importance of these minerals is summarized in Table I.

\section{MINING AND PROCESSING}

\section{Borates in salt lakes}

Ulexite appears as layers (in the shape of bars or sheets) which are actually strata $50 \mathrm{~mm}$ to $1 \mathrm{~m}$ thick, or as nodules (they are of the "potato" shape), with size up to $200 \mathrm{~mm}$.

Because of special characteristics of these salt lakes (e.g. weak foundation soil and shallow phreatic level), attempts to mine mechanically these deposits were not successful. At the present time, the mining is undeveloped, almost manual.

Ore beneficiation is simple and crude. It consists of natural drying at places far from the salt lake environment (the advantage is made of dry and windy climate at the Puna region). The "bars" and "potatoes" are subsequently cleaned by removing the waste. Approximately 1300 tonnes per month of "cleaned" ulexite (the grade of about 30 per cent of boric oxide) is used as a raw material in local boric acid plants. 
Table I Main borate minerals in the Argentina Puna. Intermediate products. Uses. $\square=\mathrm{B}_{2} \mathrm{O}_{3}$ content, Wt \%.

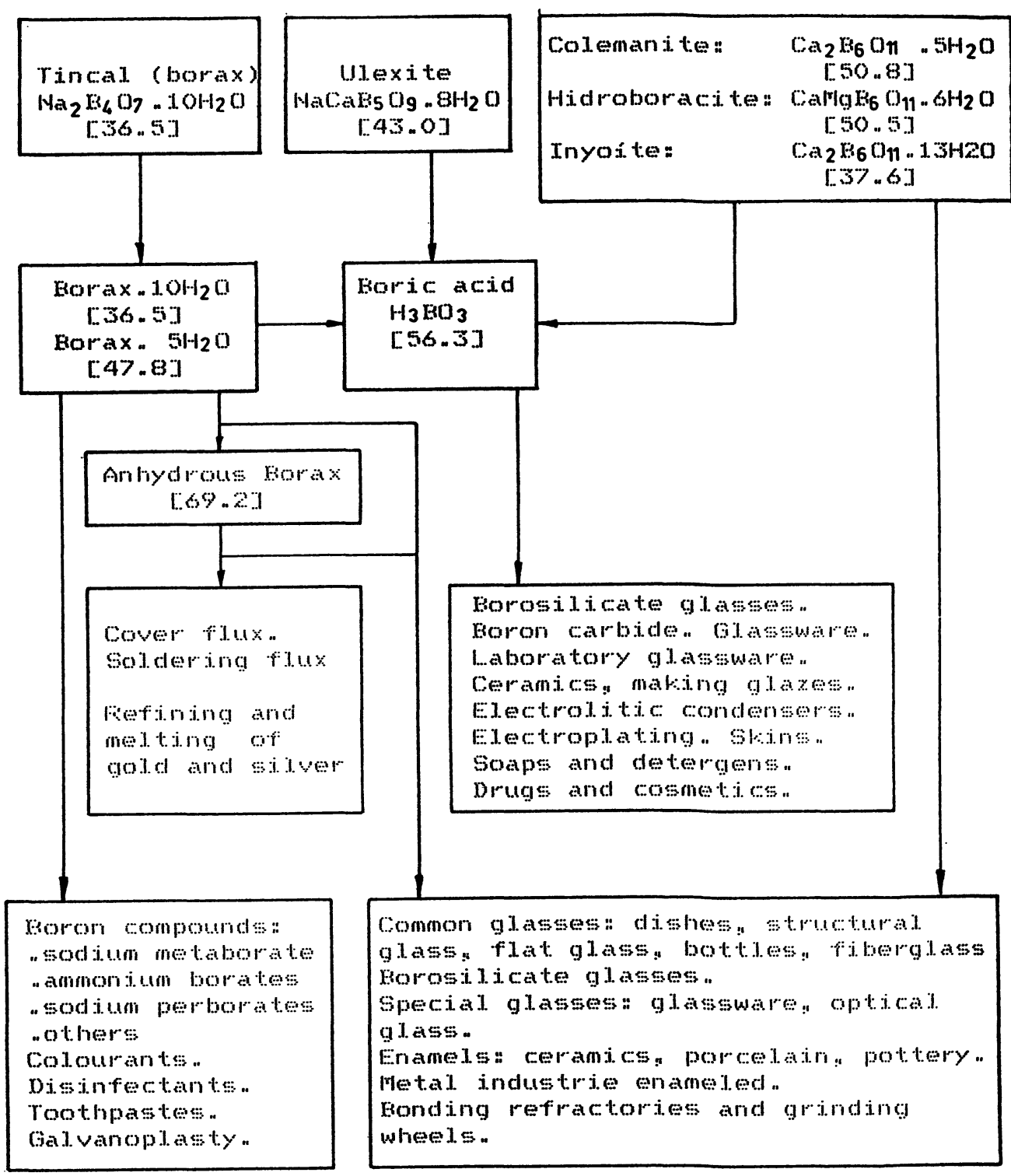


Seven out of eight plants for boric acid are situated in the Lerma Valley (Salta Province), which is an agricultural belt. Because of soil pollution, numerous public protests have been recently raised against the presence of the plants.

These difficulties in the mining, beneficiation and industrialization of borates from salt lakes revived an interest in the beneficiation of large and rich deposits of "hard" borates.

\section{Borates in rocks}

Sodium borates, either tincal (borax) or tincalconite minerals are exploited in Tincalayu and Loma Blanca mines with average grade of 17 per cent boric acid. The gangue is separated from these minerals by taking the advantage of the fact that they are easily soluble in hot water. "Borax 10" (sodium tetraborate decahydrated) is produced from the purified solution by cooling crystallization. Borax 10 can be either converted into "borax 5", dehydrated and fused into anhydrous borax, or it can be leached by acid and then converted into boric acid by crystallization. The latter processing may also be carried out by feeding either the run-of-mine ore or a previously concentrated ore. On a monthly basis, 15000 tonnes are converted into borax 10, borax 5 or anhydrous borax, and further 1000 tonnes are converted into boric acid.

Calcium and magnesium borates such as colemanite, inyoite and hydroboracite are not easily treated by wet methods, in contrast to sodium borates. They can be used to produce boric acid, although recently the concentrate of calcium borate with low sodium content is sold as a concentrate. This is the result of an increasing demand in the manufacture of fibre glass and special glasses. This is demonstrated by the fact that the production of the Salta raw borate has increased from 7600 tonnes in 1961 to 192000 tonnes in 1986, and it is expected that the consumption will reach 200000 tonnes in 1991 [4]. At the same time, however, the demand for a high-grade material increases. Brazil and Italy are the major importers of highgrade calcium borates (approximately 40 per cent boric oxide) from the Sijes deposits.

In addition to the traditional washing technique, the calcining by decrepitation is practiced at present. The method concentrates the borates as a light, very fine powder, as long as the unaltered gangue remains in the coarse fraction [5,6]. None of these techniques enable the iron impurities to be removed. 


\section{IRON IMPURITIES}

The purity of products obtained by crystallization is clearly an advantage, but it does not allow total elimination of iron in the final product, according to market requirements. Products thus must be purified repeatedly by magnetic separation [7]. In addition, there are certain specific and local limitations in the mining and the processing of borates that come from the salt lakes, as mentioned above. This situation, and the demand for hard borates led to investigations with the aim to improve previous techniques of concentration and purification.

Iron impurities in hard borates are associated with the gangue; "toba" and "tufa" rocks contain up to 3 per cent and 1 per cent, respectively, of iron oxide. Also, considerable concentration of magnetite was found in the tailings of the washing plants. Further contamination is caused by corrosion and abrasion of the grinding elements. This is observed particularly in beneficiation of colemanite which is the hardest borate mineral in the region [8].

The most exacting requirements on the borate concentrate come from the manufacturers of high-quality ceramics and glass. The main and the most common requirements are:
a. size distribution
b. grade of boric oxide
c. refractory impurities with high melting point, that do not melt during the processing in furnaces, and then appear as imperfections in glass or glazing
d. iron impurities which stain the low-grade glass and cause its characteristic green bottle-glass colour.

Iron content of nearly 0.35 per cent of ferric oxide is considered excessive and limits the use of borates in manufacture of standard glass or of boric acid. With regard to size distribution, the size range 30 to 80 mesh $(0.18$ to $0.60 \mathrm{~mm})$ is considered desirable, although it is not strictly demanded. Particles smaller than 200 mesh $(0.075 \mathrm{~mm})$ are used in ceramic and fibre glass manufacture [9]. Here, the requirement for iron content is less stringent, and up to 0.75 per cent of ferric oxide is acceptable. It is clear that the probability of introducing iron impurities increases as the requirements on size of the product decrease.

The requirements for iron content are rather flexible when the borate concentrate is used as raw material in boric acid manufacture. concentrates with 0.70 to 0.80 per cent of ferric oxide are often accepted by the market. 


\section{MAGNETIC SEPARATION TESTS}

\section{$\underline{\text { Objective }}$}

The purification of hard borates is an example of a separation process in which a small, undesired, magnetic fraction is removed from a mixture fed into the separator. The magnetic fraction is too large for a magnetic filter to be used. The main objective of this study is to demonstrate the possibility of increasing the value of hard borate concentrate by the application of magnetic separation.

A sample of colemanite ore from Sijes district was used. The feed sizes were selected to obtain two products: 30 to 80 mesh (glassware mesh) and - 80 mesh, for the manufacture of glass, ceramics and fibres.

\section{Characteristics of samples}

Samples obtained from magnetic separation tests were weighed and assayed for boric oxide, total iron and minerals insoluble in strong acid. Iron that originated in the grinding stage was determined by taking the advantage of its high solubility in strong acids. Specific magnetic susceptibility $\mathrm{K}$ (which was measured by the Gouy method) was used for preliminary assessment of results of the HMS tests $[10,11]$. The evaluation of each fraction was made by calculating the factor $k$, defined as $k$ $=\mathrm{xK} /\left(100 \mathrm{~K}_{\text {feed }}\right)$, where $\mathrm{x}$ is the fraction of solids, by weight, fed to the separator, of specific magnetic susceptibility $\mathbf{K}$.

\section{Experiments and Results}

Two samples of borate ore were prepared by stage grinding to - 30 mesh, followed by dry screening at -80 mesh. Chemical composition and physical properties of these samples are shown in Table II. It can be seen that, as a result of accumulation of impurities in small sizes, an increase in concentration of iron oxide, insoluble minerals and of magnetic susceptibility is observed.

Ferromagnetic impurities were removed from the feed by a ferromagnetic separator of a new design. The separator employs a linear magnetic field to lift and transport ferromagnetic particles. In dry separation, the ferromagnetic separator is suspended over a feed belt. 
TABLE II Chemical composition and physical properties of the feed samples

\begin{tabular}{|c|c|c|c|c|}
\hline \multicolumn{2}{|c|}{$I t e m$} & Head feed & $\begin{array}{c}30-80 \text { mesh } \\
\text { fraction }\end{array}$ & $\begin{array}{l}80 \text { mesh } \\
\text { fraction }\end{array}$ \\
\hline \multicolumn{2}{|l|}{ Weight. $\because$} & 100 & 16.0 & 84.0 \\
\hline $\begin{array}{l}\text { Chemical } \\
\text { composition }\end{array}$ & $\begin{array}{l}\mathrm{B}_{2} \mathrm{O}_{3} \\
\mathrm{Ins}=0 \text { lubel } s \\
\mathrm{~F} \in 2 \mathrm{O}_{3}\end{array}$ & $\begin{array}{r}26.90 \\
26.20 \\
1.19\end{array}$ & $\begin{array}{r}30.57 \\
1.3 .70 \\
0.47\end{array}$ & $\begin{array}{r}26.13 \\
28.55 \\
1.31\end{array}$ \\
\hline \multicolumn{2}{|c|}{$\begin{array}{l}\text { Average particle size; } \mathrm{mm} \\
\text { Specific weight, g/cm } \\
\text { Sp.SI susceptibility: } \mathrm{m}^{3} / \mathrm{kc}\end{array}$} & $+\cdots$ & $\begin{array}{rl}0.311 \\
2.49 \\
4.7 & 1.0\end{array}$ & $\begin{array}{l}0.077 \\
2.39 \\
7.110\end{array}$ \\
\hline
\end{tabular}

The feed is introduced as a thin layer on a feed belt, and is transported into the magnetic field created by electromagnetic coils. The separator has a magnetic core with many comb-shaped pole-pieces. The coils are connected to a three-phase power source with controlled frequency. The alternating current that passes through the windings generates a moving linear magnetic field which attracts ferromagnetic particles and transports them to a discharge point, as is shown in Figure 2. Details of the separator will be published later.

\section{$\underline{30-80 \text { mesh fraction }}$}

This fraction was fed into the ring magnetic separator that worked at several values of the magnetic field strength. A belt was used to transport the feed material into two regions of the magnetic field and then to transport the tailings out of the magnetic system. Ferromagnetic particles are removed in the first region, as discussed above. In the other region, the magnetic particles attracted from the feed are thrown sideways by a disc suspended over the belt, as is shown in Figure 2. 

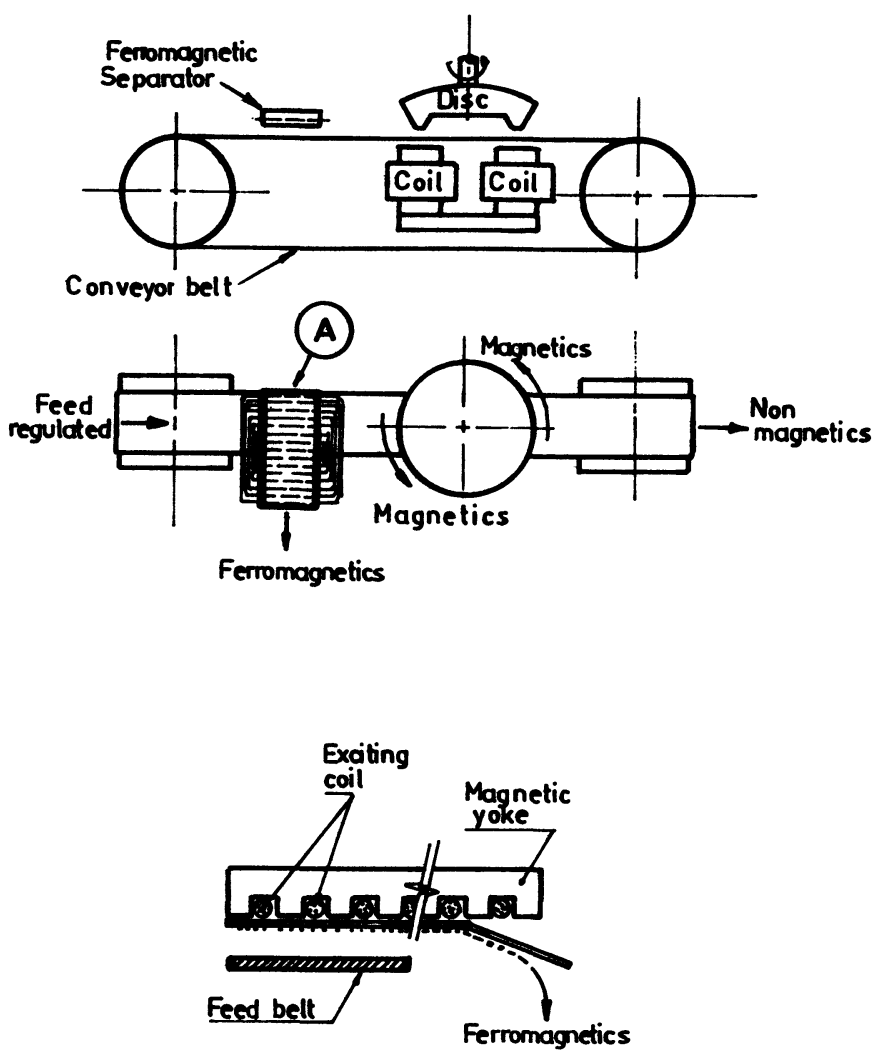

(A) Side view diagram of ferromagnetic separator

FIGURE 2 The ring-type magnetic separator

The air gap was kept constant at $3 \mathrm{~mm}$ in each test. The values of the magnetic factor $\mathbf{k}$ for each sample, as a function of the magnetic field strength are depicted in Figure 3. It can be seen that the non-magnetic fraction achieves the minimum value at $0.6 \mathrm{~T}$. At the magnetic field strength the iron content is reduced to 0.28 per cent of ferric oxide which is in accordance with the market requirements for pardcent of ferric oxide which is in accordance with the market requirements for hard borates. A higher magnetic field is not effective in reducing the iron content further. The mass yield into the non- magnetic fraction exceeded 92 per cent in all tests. The results are summarized in Table III. Concentration of boric oxide in the non-magnetic product increased by 0.7 to 1.5 per cent compared to the feed. Consequently, the recovery of boric oxide was almost equal to the mass yield. 


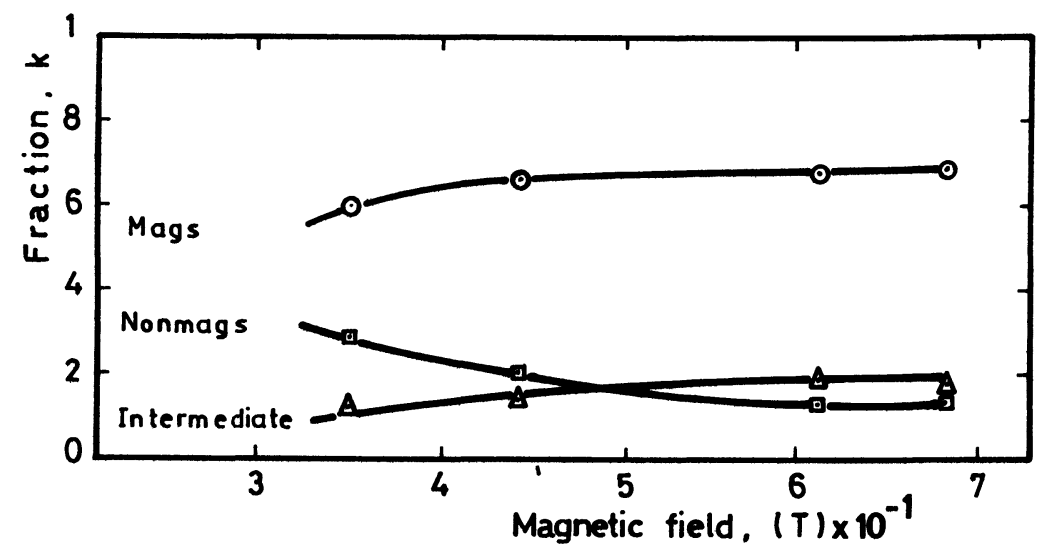

FIGURE 3 Magnetic separation in the ring magnetic separator. Feed: $30-80$ mesh.

\section{-80 mesh fraction}

As a result of cohesion forces between the particles, dry magnetic separation is not a suitable technique to beneficiate fine samples. However, taking advantage of extremely dry climate in the Puna (25 per cent average relative humidity) two tests were carried out using the ring magnetic separator. High values of factor $\mathbf{k}$ corroborate poor results obtained in those tests. Concentration of ferric oxide of nearly 1.2 per cent, as shown in Table III is too high for the borates to be used as a raw material in the ceramics.

Although wet magnetic separation was excluded in the beginning in order to avoid solid-liquid separation, several tests were carried out at a later stage. A continuous pilot- plant HGMS separator shown in Figure 4 [12] was used in the trials. The carousel of the separator was filled either with stainless-steel balls, $5 \mathrm{~mm}$ in diameter, or with steel plates, as shown in Figure 5. The matrix height was $100 \mathrm{~mm}$ for each run. Samples in the form of a slurry (20 per cent w/w) were gravity-fed from a head tank. The magnetics and the non-magnetics were collected, filtered, dried, weighed and analysed. 
TABLE III Results of magnetic separation in the ring magnetic separator

\begin{tabular}{|c|c|c|c|c|c|}
\hline $\begin{array}{l}\text { Magnet.i.c } \\
\text { fi.e id }\end{array}$ & Fraction & $\begin{array}{l}\text { artadi. } \\
\text { weight } \\
x \quad(\because)\end{array}$ & $\begin{array}{l}\text { Specific: si } \\
\text { susceptib. } \\
\text { K } 10^{7}\left(\mathrm{~m}^{3} / \mathrm{kg}\right)\end{array}$ & $\begin{array}{c}\text { Fraction } \\
\text { k prop. } \\
\text { r. }\end{array}$ & $\begin{array}{c}F \in 2 O_{3} \\
\text { content } \\
(\because)\end{array}$ \\
\hline & 30 -..80 | fred & 100 & 4.7 & 1. & 0.47 \\
\hline $0.36 r$ & $\begin{array}{l}\text { Magmetic: } \\
\text { lontermed a te } \\
\text { Nommagneti }\end{array}$ & $\begin{array}{r}0.7 \\
1.1 \\
9.2\end{array}$ & $\begin{array}{l}40 \% \\
51.0 \\
1.34\end{array}$ & $\begin{array}{l}0.60 \\
0.12 \\
0.20\end{array}$ & \\
\hline $6.44 T$ & $\begin{array}{l}\text { Magnetic: } \\
\text { Tn termediate: } \\
\text { Monmagnet.i. }\end{array}$ & $\begin{array}{r}1.2 \\
2.0 \\
6.9\end{array}$ & $\begin{array}{l}266 \\
3.9 \\
0.99\end{array}$ & $\begin{array}{l}0.66 \\
0.14 \\
0.20\end{array}$ & \\
\hline $0.58 r$ & $\begin{array}{l}\text { Magnetic: } \\
\text { Totemmed a te: } \\
\text { Nonmagneti.: }\end{array}$ & $\begin{array}{r}1 . .6 \\
4.7 \\
9.7\end{array}$ & $\begin{array}{l}206 \\
1.6 .5 \\
0.6 \%\end{array}$ & $\begin{array}{l}0.69 \\
0.19 \\
0.1 \%\end{array}$ & $\begin{array}{l}5.48 \\
2.32 \\
0.28\end{array}$ \\
\hline $0.6 \% r$ & $\begin{array}{l}\text { Magnetic: } \\
\text { Tntemediate } \\
\text { Nonmagnetic: }\end{array}$ & $\begin{array}{r}1 . .6 \\
6.3 \\
9.1\end{array}$ & $\begin{array}{l}1.97 \\
1.4 .8 \\
0.69\end{array}$ & $\begin{array}{l}0.69 \\
0.18 \\
0.1 \%\end{array}$ & \\
\hline & $<80$ mesh feed & 100 & 7.1 & $I$ & 1.31 \\
\hline $0.44 r$ & 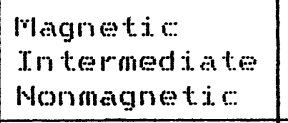 & $\begin{array}{r}0.6 \\
9.6 \\
9.8 \\
\end{array}$ & $\begin{array}{r}469 \\
199 \\
3.07 \\
\end{array}$ & $\begin{array}{l}0.40 \\
0.17 \\
0.43 \\
\end{array}$ & 1.20 \\
\hline $0.76 \mathrm{r}$ & $\begin{array}{l}\text { Magnetic: } \\
\text { Tntermedi. ate: } \\
\text { Monmagneti.: }\end{array}$ & $\begin{array}{r}1 . .3 \\
2.08 \\
9: .9\end{array}$ & $\begin{array}{r}310 \\
31.0 \\
2.5\end{array}$ & $\begin{array}{l}0.55 \\
0.12 \\
0.32\end{array}$ & I. $1 . \%$ \\
\hline
\end{tabular}

The results (Table IV) show that the removal of iron impurities was the same using either steel plates at $0.41 \mathrm{~T}$ or steel balls at $0.16 \mathrm{~T}$. The residual iron, between 1.15 and 1.16 per cent ferric oxide, is still too high to meet the industrial requirements ( 0.7 per cent). Tests performed at $0.45 \mathrm{~T}$ using the steel ball matrix gave the iron content acceptable by the market, the recovery was, however, less than 80 per cent. 
TABLE IV Test runs in matrix-type magnetic separator

\begin{tabular}{|c|c|c|c|c|c|c|}
\hline \multirow{2}{*}{$\begin{array}{l}\text { Magnetic: } \\
\text { fi.eld } \\
\text { I. mat ri x I }\end{array}$} & \multirow[t]{2}{*}{ Fraction } & \multirow{2}{*}{$\begin{array}{c}\text { Fartiat } \\
\text { weight } \\
x \\
(\because)\end{array}$} & \multirow{2}{*}{ 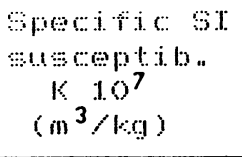 } & \multirow{2}{*}{$\begin{array}{c}\text { raction } \\
\text { K prop. } \\
\text { r. }\end{array}$} & \multicolumn{2}{|c|}{$\begin{array}{l}\text { Choni cal } \\
\text { (omp. (a) }\end{array}$} \\
\hline & & & & & $\mathrm{H}_{2} \mathrm{O}_{3}$ & $F \in 2 O_{3}$ \\
\hline & 80 mesh & 100 & 7.1 & 1. & 26 . & I. . \\
\hline $\begin{array}{l}0.41 . \mathrm{r} \\
\text { I.. plates tes }\end{array}$ & $\begin{array}{l}\text { Magls } \\
\text { Intermed. } \\
\text { Nonmags }\end{array}$ & $\begin{array}{r}1 . .6 \\
\vdots .4 \\
9.8\end{array}$ & $\begin{array}{l}160 \\
29,1 \\
2.74\end{array}$ & $\begin{array}{l}0.42 \\
0.2 \% \\
0.36\end{array}$ & & 1. .16 \\
\hline $\begin{array}{l}0.16 \mathrm{~T} \\
{[. \operatorname{tod} 1 \leq]}\end{array}$ & $\begin{array}{l}\text { Mags } \\
\text { Intermed.. } \\
\text { Nonmags }\end{array}$ & 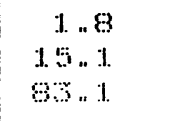 & $\begin{array}{r}139 \\
1.6 .2 \\
2.8\end{array}$ & $\begin{array}{l}0.36 \\
0.35 \\
0.30\end{array}$ & & 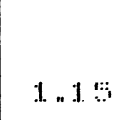 \\
\hline $\begin{array}{l}0.45 r \\
\text { \% bat } 1=1\end{array}$ & $\begin{array}{l}\text { Mags } \\
\text { Tnterined " } \\
\text { Nonmags }\end{array}$ & 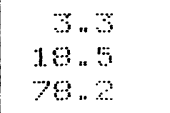 & $\begin{array}{l}10 \% \\
13.6 \\
1.2\end{array}$ & $\begin{array}{l}0.51 \\
0.35 \\
0.1 .3\end{array}$ & $\begin{array}{l}18.2 \\
2: 5.1 \\
26.6\end{array}$ & $0.6 \%$ \\
\hline
\end{tabular}

In spite of this, HGMS is a promising alternative in view of the fact that the concentration of boric oxide in the middlings and in the non-magnetic fraction is not affected by magnetic separation. As a result of suitable particle size distribution and of less stringent requirements for iron content the middlings and/or the concentrate can thus be used as a raw material in manufacture of boric acid.

Further investigations are needed since our results do not apply to other deposits even though they have characteristics similar to those of the Sijes ore.

\section{CONCLUSIONS}

Hard borate deposits in the Argentine Puna represent the biggest reserves of hydroboracite in the world, and the most extensive reserves of colemanite and inyoite in South America.

In the last two decades, the borate deposits in the Argentine Puna have been exploited and the region, particularly the Salta province is the fifth largest exporter of the borates in the world.

Magnetic separation of iron impurities is an exciting technological challenge to upgrade hard borates and enables them to be marketed as raw material in glass and ceramics industries. 


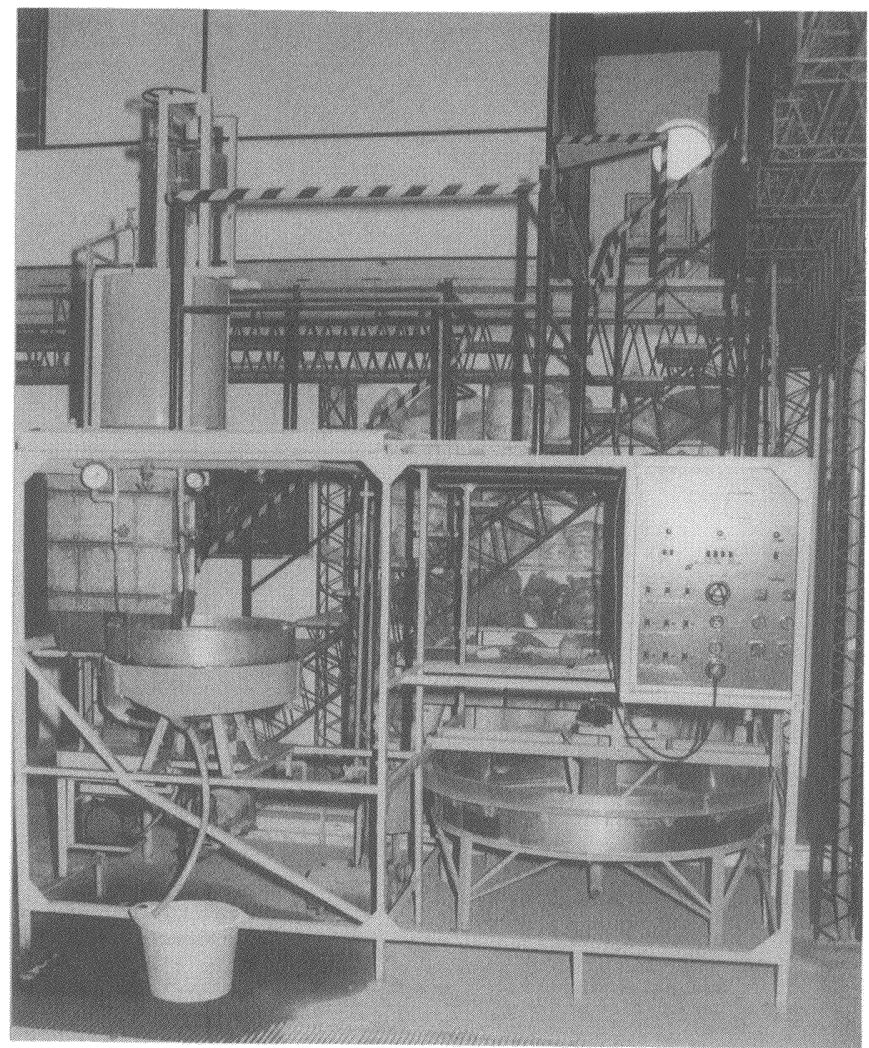

FIGURE 4 The pilot-plant HGMS separator

\section{ACKNOWLEDGMENTS}

The authors are grateful to Mr. R. Pocovi and Mrs. L. Mattenella for valuable discussions and to Mrs. M. Fairhurst for her assistance in translating the draft of the paper. 


\section{a) Stainless steel balls}
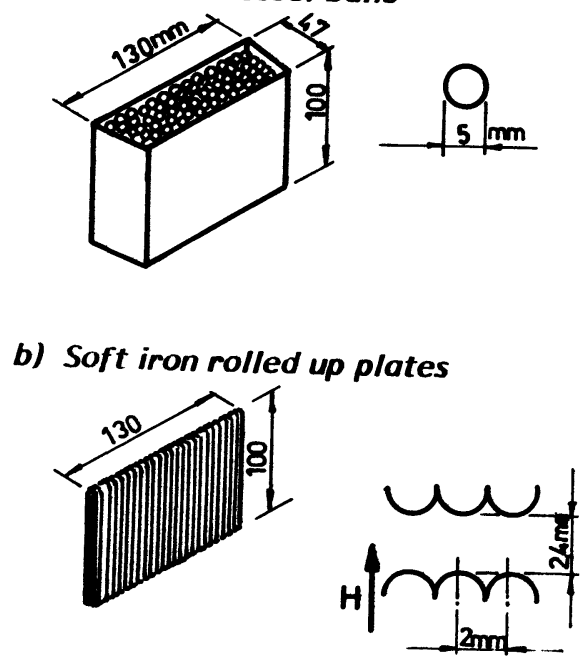

FIGURE 5 Matrices used in HGMS

\section{REFERENCES}

1. A.P. Igarzabal and R.N. Alonso, Panorama Minero 145,30 (1990)

2. N. Nanni and P.H. Alurralde, Ingenieria Quimica 223, 115 1988)

3. R.N. Alonso and C.E. Gonzales Berry, Goelogy and distribution of borate deposits in the mining district of Sijes, Salta. Proc. IV Jornada Argentinas de Ing. Minas, Jujuy, Argentina, II, 55 (1990)

4. Estadistica minera de la Republica Argentina (Buenos Aires, Argentina, 1988)

5. N.L. Weiss (Ed.), SME Mineral Processing Handbook, 2, 29 (1985)

6. A.A. Latre and H.R. Flores, Calcination of colemanite, Report INBEMI, Salta, Argentina, 1991

7. N.P. Nies, Boron oxides, boric acids and borates, ECT, 2nd ed., $\underline{3}$ (4), 1972

8. L.F. Aristarain and C.S. Hurlbut, The Mineral Record, 3(4) (1972) 
9. L. Totino, Panorama Minero 125,18 (1990)

10. H.R. Flores and G. Villaflor, Design and calibration of a balance for the measurement of magnetic susceptibility of paramagnetic materials (To be published in Rev. Latinoamer. Met. Mater, Venezuela)

11. H.R. Flores and A.I. Redondo, Rev. Metal. CENIM 26(2), 86 (1990)

12. H.R. Flores et al., Design of a high-intensity and high-gradient wet pilot-plant magnetic separator. Proc. VIII Congreso Chileno de Ing. Qca., Antofagasta (Chile), (1986)

H.R. Flores graduated in chemical engineering from the National University of Tucaman, Argentina, in 1972. He has been a member of a research group in mineral processing since 1973 and a scientific and technological researcher at CONICET (Argentina). Professor Flores is a vicedirector of the Mineral processing Institute, INBEMI (U.N.Sa. CONICET) and a professor of mineral processing at the National University of Salta (U.N.Sa.)

$\mathrm{He}$ is a member of the Argentine Association of Researchers in Chemical Engineering and Applied Chemistry (AADICIQA), Argentina and of the Professional Society of Chemical engineeris in Salta. He is an author of more than 15 papers and 30 communications.

P.D. Villagran is a fellow of the Consejo de Investigacion, National University of Salta, Argentina.

Keywords: borates, colemanite ore, salt lakes, iron impurities, ferric oxide, magnetic separation. 